\title{
Dinar (Afyonkarahisar) Havzasındaki Su Kaynaklarının Hidrojeokimyasal Özelliklerinin Değerlendirilmesi
}

\author{
Fatma AKSEVER*1, Mehmet Yunus LALE1, Fatih MACI'T1
}

${ }^{1}$ Süleyman Demirel Üniversitesi, Mühendislik Fakültesi, Jeoloji Mühendisliği Bölümü, 32260, Isparta

(Alınıș / Received: 15.06.2017, Kabul / Accepted: 20.02.2018, Online Yayınlanma / Published Online: 04.05.2018)

\section{Anahtar Kelimeler}

Dinar havzası,

Su kaynakları,

Hidrojeokimya,

İçme suyu kalitesi
Özet: Dinar havzası Büyük Menderes havzasının bir alt havzasıdır. Bu çalışmada, Dinar havzasındaki su kaynaklarının hidrojeokimyasal özellikleri detaylı olarak incelenmiştir. $\mathrm{Bu}$ amaçla çalışma alanındaki içme suyu kaynaklarından su örnekleri alınmıştır. Kaynak sularının sıcaklıkları $15.50-19.90^{\circ} \mathrm{C}, \mathrm{pH}$ değerleri 7.54- 8.76, toplam çözünmüș katı madde miktarı 110-402 mg/L, çözünmüș oksijen miktarı 0.06-0.10 mg/L, redoks potansiyeli 242.5-340.0 mV, elektriksel iletkenlikleri (EC) $300-700 \mu \mathrm{S} / \mathrm{cm}$ ve sertliği ise 15.76-31.29 $\mathrm{Fr}^{\circ}$ arasındadır. Suların iyon derişimi ise $\mathrm{Ca}^{+2}>\mathrm{Mg}^{+2}>\mathrm{Na}^{+}>\mathrm{K}^{+}$ve $\mathrm{HCO}_{3}>\mathrm{SO}_{4}^{-2}>\mathrm{Cl}^{-}>\mathrm{CO}_{3}{ }^{-2}$ şeklindedir. Kaynak suları genel olarak $\mathrm{CaMgHCO}_{3}{ }^{\prime} \mathrm{l} ı$ su tipinde, Pınarlı su kaynağı ise $\mathrm{CaHCO}_{3}{ }^{\prime} \mathrm{l}_{\imath}$ su tipindedir. Ayrıca kaynak suları Gibbs diyagramına göre su-kayaç etkileşimli bölgededir. Sularda azot türevleri ve iz elementler açısından arsenik (As) konsantrasyonu artışı dışında negatif etki gözlenmemiştir. Kaynak sularında As içeriği sınır değeri aşmaktadır. Bu artışın jeojenik olarak su-kayaç etkileşimine bağlı olduğu düşünülmektedir.

\section{Hydrogeochemical Characteristics of Assessment of Water Springs in the Dinar (Afyonkarahisar) Basin}

\section{Keywords}

Dinar basin,

Water springs,

Hydrochemistry,

Drinking water quality

\begin{abstract}
Dinar basin is a sub-basin of Büyük Menderes basin. In this study, the hydrogeochemical properties of the water springs have been studied in detail in the Dinar basin. For this purpose, water samples were taken from the drinking water springs in the study area. Accordingly the temperature of the spring waters range from 15.50 to $19.90^{\circ} \mathrm{C}$, the $\mathrm{pH}$ values from 7.54 to 8.76 , the total dissolved solids amount from 110 to $402 \mathrm{mg} / \mathrm{L}$, the dissolved oxygen amount from 0.06 to $0.10 \mathrm{mg} / \mathrm{L}$, the redox potential from 242.5 to $340.0 \mathrm{mV}$, the electrical conductivities (EC) from 300 to $700 \mu \mathrm{S} / \mathrm{cm}$ and the hardness from 15.76 to $31.29 \mathrm{Fr}^{\circ}$, respectively. The relative abundance of the ions is $\mathrm{Ca}^{+2}>\mathrm{Mg}^{+2}>\mathrm{Na}^{+}>\mathrm{K}^{+}$and $\mathrm{HCO}_{3}$ $>\mathrm{SO}_{4}{ }^{-2}>\mathrm{Cl}>\mathrm{CO}_{3}{ }^{-2}$. Generally, spring waters are of $\mathrm{CaMgHCO}_{3}$ water type and Pinarlı spring is of $\mathrm{CaHCO}_{3}$ water type. According to the Gibbs diagram the spring waters are in the water-rock interaction zone. In addition, the nitrogen components and trace elements have no negative effects except for an increase in As concentration. The As content exceeds the limit value in the spring waters. This increase is thought to be geogenic related to the water-rock interaction.
\end{abstract}

\section{Giriș}

Günümüzde artan nüfusa bağlı olarak içme suyu ihtiyacı da günden güne artmaktadır. Buna bağlı olarak kentleșme, endüstrileșme, küresel isınma, çevre kirliliği vb. gibi unsurlar içme suyu kaynağımız olan yeraltı sularını doğrudan ya da dolaylı olarak olumsuz yönde etkilemektedir. Özellikle de yeraltı sularımızı bilinçsizce ve kontrolsüzce tüketimimiz gelecekte doğal su kaynaklarımızı tehdit etmektedir.
$\mathrm{Bu}$ nedenle doğal boşalıma sahip olan mevcut su kaynaklarımızın belirlenmesi, değerlendirilmesi ve korunması için gerekli çalışmaların yapılması zorunlu hale gelmektedir. $\mathrm{Bu}$ tarz çalışmaların etkin olmasında doğal su kaynaklarının hidrojeokimyasal açıdan detaylı olarak incelenmesi ön plana çıkmaktadır.

Çalışma alanı olarak seçilen Dinar havzasında yüksek debiye sahip çok sayıda su kaynakları mevcuttur. 
Kaynak suları bölgede içme ve sulama amaçlı olarak kullanılmaktadır. Ayrıca bu kaynaklar birleşerek Büyük Menderes Nehri'nin doğduğu yeri oluşturmaktadır. Bu nedenle inceleme alanında yer alan su kaynaklarının kalitesi ve kontrolü büyük önem taşımaktadır. Bu çalışma, Dinar havzasında bulunan su kaynaklarının hidrojeokimyasal olarak değerlendirilmesini kapsamaktadır.

\section{Materyal ve Metot}

Çalışma kapsamında öncelikle, Dinar havzasına ait 1/100000 ölçekli jeoloji haritası önceki çalışmalar doğrultusunda revize edilerek hazırlanmıştır. Çalışma alanında bulunan litolojik birimler akifer olabilme özelliklerine göre sınıflandırılmış ve jeoloji haritası üzerinde gösterilmiştir. İnceleme alanında toplam 6 ayrı su kaynağından su örnekleri alınmıştır. Örnekler plastik sızdırmaz kapaklı, $100 \mathrm{ml}$ ve steril olan şişelere alınmış ve üzerine $\mathrm{pH}<2$ olacak şekilde konsantre ve yüksek saflıkta $\mathrm{HCl}$ (hidroklorik asit) ilave edilmiştir (katyon analizi için). Örneklerin koordinatlarını belirlemek için Magellan Triton 500 marka GPS kullanılmış ve örnek lokasyonları jeoloji haritası üzerine işlenmiştir. Su örneklerine ait $\mathrm{pH}$, sıcaklık (T), redoks potansiyeli (Eh), elektriksel iletkenlik (EC) ve toplam çözünmüş madde (TDS) gibi fiziksel özellikler YSI (US) 556-01 MPS marka taşınabilir cihaz ile yerinde ölçülmüştür. Kimyasal ve azot türevlerinin analizleri Hacettepe Üniversitesi $\mathrm{Su}$ Kimyası ve Çevresel Trityum laboratuvarında yapılmıştır. Kimyasal analizlerde APHA (American Public Health Association), AWWA (American Water Work Association) ve WPCF (Water Pollution Control Federation) tarafindan hazırlanan Standard Methods For the Examination of Water and Waste Water test standartları uygulanmıştır. İz elementler ise Canada Bureau Veritas Mineral Laboratories (Acme Analitik Laboratuvarında), Inductively Coupled Plasma - Mass Spectrometer (ICP-MS) cihazı ile belirlenmiștir. Elde edilen kimyasal veriler Piper [1], Chadha [2], Gibbs [3], Schoeller, ABD Tuzluluk Laboratuvarı [4] ve Wilcox [5] diyagramları ile yorumlanmıştır.

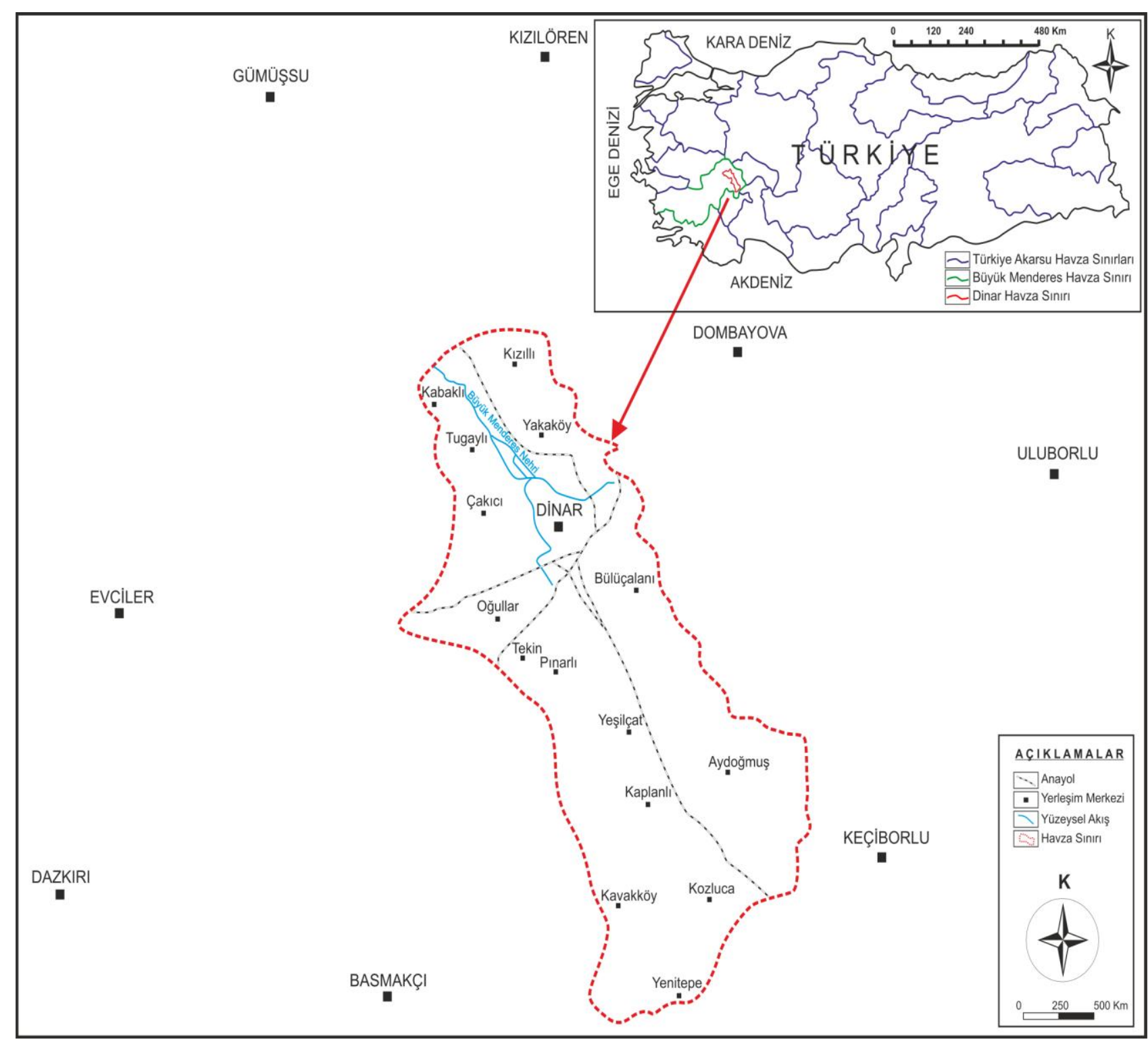

Şekil 1. İnceleme alanı yer bulduru haritası 


\section{Bulgular}

\section{1. Çalıșma alanı}

Çalışma alanı Ege bölgesinin batısında yer almaktadır. Kuzeydoğu-güneybatı uzanımlı bir yapıya sahip olan Dinar havzası, Büyük Menderes havzasının alt havzası konumundadır (Şekil 1). En önemli yüzeysel akışı olan Büyük Menderes Nehri sayesinde Dinar havzası yarı kapalı havza özelliği kazanmaktadır. $20 \mathrm{~km}$ uzunluk ve 8-10 km genişlik ile etrafı yükseltilerle çevrili olan Dinar ovasını oluşturan çukurluk Dinar grabeni ile şekillenmektedir.

\subsection{Jeoloji}

Çalışma alanı ve yakın çevresinde allokton, otokton, paraallokton konumlu birimler ve örtü kayaları yer almaktadır. Allokton konumlu birimler Yeşilbarak ve Likya naplarına ait kayalardır. Yeşilbarak napı çalışma alanında Orta-Geç Eosen yaşlı, kumlu-killi kireçtaşı, kalsitürbidit ve mikritik kireçtaşı ara seviyeli kumtaşı, kiltaşı ve silttaşlarından oluşan [6] Yavuz formasyonu ile temsil edilmektedir. Likya napları ise Marmaris ofiyolit napına ait $\mathrm{Geç}$ Senoniyen yaşlı Kızılcadağ melanjı ve olistostromu ile Domuz napına ait Dutdere kireçtaşı ile temsil edilir. Kızılcadağ melanjı ve olistostromu, serpantinit, serpantinleşmiş harzburjit, dunit vb. ultramafikler ve kırıntılılardan oluşan bir hamur içerisinde radyolarit, çörtlü kireçtaşı, neritik kireçtaşı ile spilitik bazalt, tüf, tüfit, gabro, diyabaz, harzburjit, dunit gibi bloklar içermektedir. Orta Triyas-Liyas yaşlı Dutdere kireçtaşı ise, çörtlü, ammonitli yumrulu kireçtaşlarından [7] oluşmaktadır.

Anamas-Akseki otoktonuna ait Geyikdağ birliği kayalarının alt birimi olan Kırdağ Anamasdağ biriminin içerisindeki Gökhacıdağ ve Büyükkırtepe formasyonları ise çalışma alanındaki otokton birimlerdir. Eosen yaşlı Gökhacıdağ formasyonu dolomit mercekleri içeren biyomikritli, neritik kireçtaşlarından oluşmaktadır. Kretase yaşlı Büyükkırtepe formasyonu ise resifal ve türbiditik seviyeli pelajik faunalı kireçtaşlarından oluşmaktadır. Oligosen yaşlı Akçaköy formasyonu karbonat çimentolu konglomeralardan oluşmuştur ve Likya napları üzerinde paraallokton konumludur [8]. Çalışma alanında izlenen örtü kayalarını ise; Orta-Geç Miyosen yaşlı Çamova üyesi: kumtaşı, çamurtaşı, marn vb. [9]; Çameli formasyonu: kiltaşı, marn, konglomera ve kumtaşları; Pliyosen yaşlı Kireçtaşı üyesi: killi kireçtaşı, kireçtaşı, traverten, PliyoKuvaterner yaşlı Kepeztepe formasyonu: kumtaşı mercekli çakıltaşları ve Kuvaterner yaşlı alüvyon, yamaç molozu ve eski akarsu taraça dolgusu oluşturmaktadır [10] (Şekil 2).

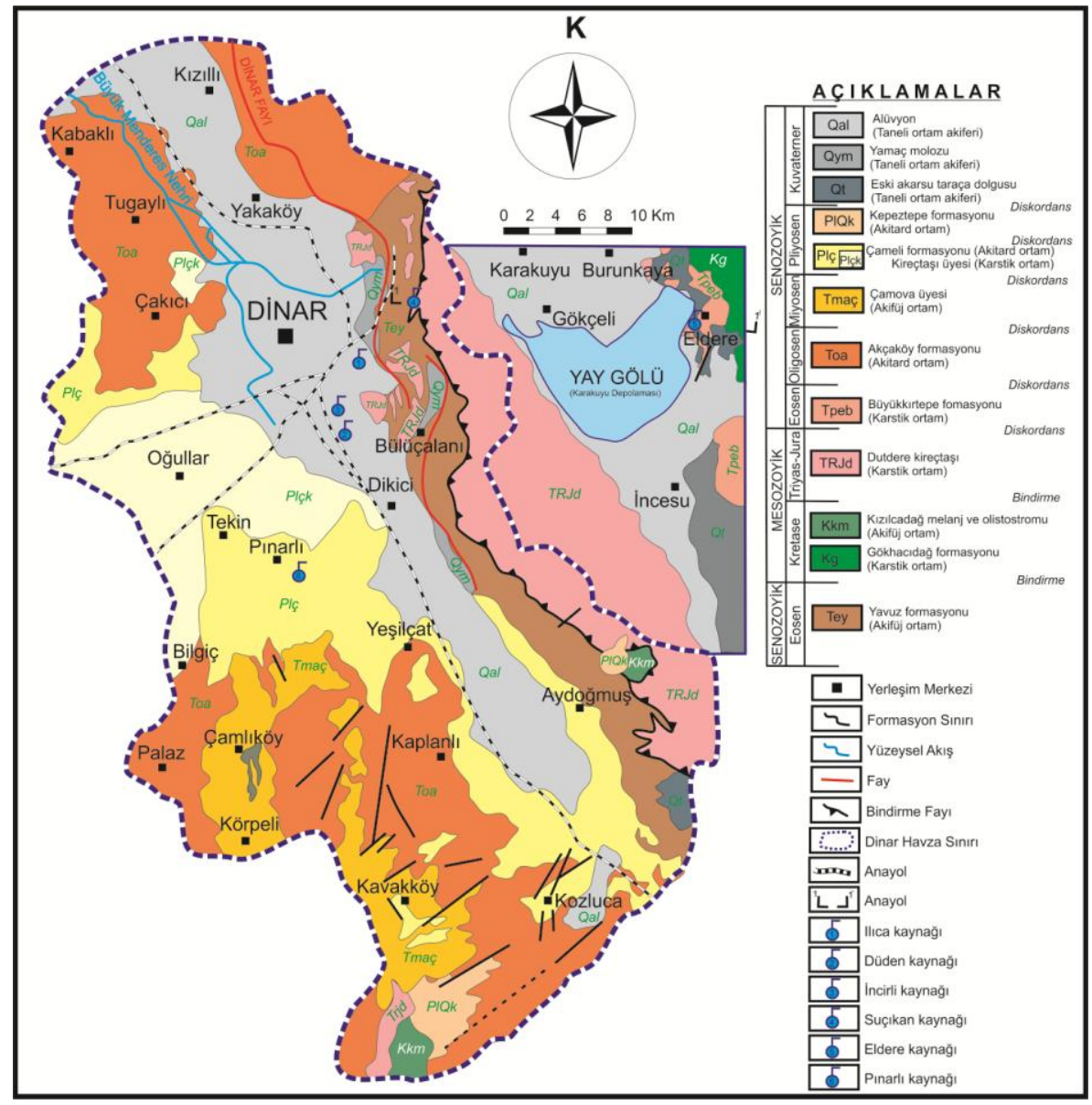

Şekil 2. İnceleme alanı jeoloji-hidrojeoloji haritası [10] 


\subsection{Hidrojeoloji}

Çalışma alanı içerisinde yer alan litolojik birimler hidrojeolojik özelliklerine göre değerlendirilerek sınıflandırılmıştır. Alüvyon; kil, silt, kum, çakıl, blok boyutundaki malzemeler ve bunların değissik kombinasyonlarının ardalanmasından oluşmaktadır. Ovada geniş yayılıma sahip olan alüvyon, pekleşmemiş çakıl ve kum seviyelerinden önemli miktarda su alınabilen "Taneli ortam akiferi" özelliğindedir. Bölgede serbest akifer niteliği taşıyan alüvyon üzerinde açılmış sondaj kuyuları bulunmaktadır. Kaplanlı ve Aydoğmuș köyleri arasinda yer alan sondaj kuyusunun verimi $17 \mathrm{l} / \mathrm{s}$ ve Dinar merkezde açlan kuyunun verimi ise $45 \mathrm{l} / \mathrm{s}^{\prime} \mathrm{dir}$ [11]. Alüvyon ile iç içe girmiş ve yer yer üzerlerine gelen, yamaç molozu ve eski akarsu taraça dolgusu da, gözenekli yapıları ile ekonomik oranlarda verimli yeraltısuyu alınabilen birimlerdir. Bu birimler de bölgede "Taneli ortam akiferi" temsil etmektedir.

Rekristalize kireçtaşlarından oluşan Dutdere kireçtaşı, kireçtaşı ve travertenden oluşan Kireçtaşı üyesi, pelajik faunalı kireçtaşlarından oluşan Büyükkırtepe formasyonu ve neritik kireçtaşlarından oluşan Gökhacıdağ formasyonu bol kırıklı ve çatlaklı yapıları ile geçirimli bir özellik sunmaktadır. Erime çatlaklı kaya niteliğindeki kireçtaşları "karstik ortam akiferi" olarak isimlendirilmiştir. Bülüçalan ve Aydoğmuş yerleșim merkezlerinin civarında açılmıș sondaj kuyularında Dutdere kireçtaşları kesilmiş konumdadır. Kuyuların debileri 16-27 l/s arasında değişmektedir [11]. Ayrıca, bölgedeki kireçtaşlarından boşalan, Eldere kaynağı, Suçıkan kaynağı, Düden kaynağı ve Bülüçalan karstik kaynakları bu karstik sistemle beslenmektedir. Oğullar mevkiinde açlan sondaj kuyularında ise Kireçtaşı üyesine girilmiş olup bu kuyuların verimi 22-40 l/s arasında belirlenmiştir [11].

Gölsel tortullardan oluşan Çameli formasyonunun içerdiği kumtaşları ve konglomeralar birimin geçirgenliğini artırmaktadır. Ancak birim içindeki kiltaşı ve marn seviyeleri ise geçirimsizdir. Kepeztepe formasyonu kumtaşı mercekli çakıltaşlarından oluşmaktadır. Birimin içerdiği çakıltaşları gevşek tutturulmamış kum veya karbonat çimentolu olması nedeniyle geçirgen özelliğe sahipken kuvars, ofiyolit, şist parçalarından oluşan kumtaşlarının seviyeleri ise geçirimsizdir. Çakıcı ve Kaplanlı yerleşim merkezlerinde açılmış sondaj kuyularında karbonat çimentolu konglomeralardan oluşan Akçaköy formasyonu kesilmiş olup bu kuyuların debileri 4863 l/s arasındadır [11]. Yarı geçirimli özelliğe sahip Çameli, Kepeztepe ve Akçaköy formasyonları "akitard ortam" olarak nitelendirilmiştir.

Karasal karakterde kumtaşı, çamurtaşı ve marnlardan oluşan Çamyuva üyesi geçirimsizdir. Diğer bir geçirimsiz birim ise, serpantinit, serpantinleşmiş harzburjit, dunit vb. ultramafikler ve kırıntılardan oluşan Kızılcadağ melanjı ve olistostromudur. Yavuzlar formasyonu da kumlu-killi kireçtaşı, kalsitürbidit ve mikritik kireçtaşı ara seviyeli kumtaşı, kiltaşı ve silttaşlarından oluşmaktadır. Birimde üste doğru kireçtaşı oranı azalır. İçerdiği kiltaşı ve silttaşlarından dolayı hidrojeolojik olarak geçirimsiz olan birim, "akifüj ortamı" temsil etmektedir (Șekil 2).

\subsection{Hidroloji}

Bölgedeki en önemli akarsu, Büyük Menderes havzasına ismini veren, Suçıkan kaynağından Dinar havzası çıkışına kadar olan tüm yüzeysularını toplayarak akış gösteren ve Dinar havzasının kuzeybatısında kalıp Işılklı Gölü'nü besleyen Büyük Menderes Nehri'dir. Nehir Dinar havzası içerisinde Dinarsuyu adını almaktadır. Ayrıca, inceleme alanında tektono-karstik yapıda çok sayıda su kaynağı bulunmaktadır.

Eldere kaynağı: Kaynak Büyükkırtepe formasyonuna ait resifal kireçtaşlarından boşalan karstik bir kaynaktır (Şekil 3). Dinar havzası dışında kalan kaynak, havzanın kuzeydoğusunda yer alan Dombayova havzasindan beslenmekte ve Dinar ilçesinin içme suyu teminini sağlamaktadır. Eldere kaynağı yörede Pınarbaşı, Kocapınar ve Ulupınar

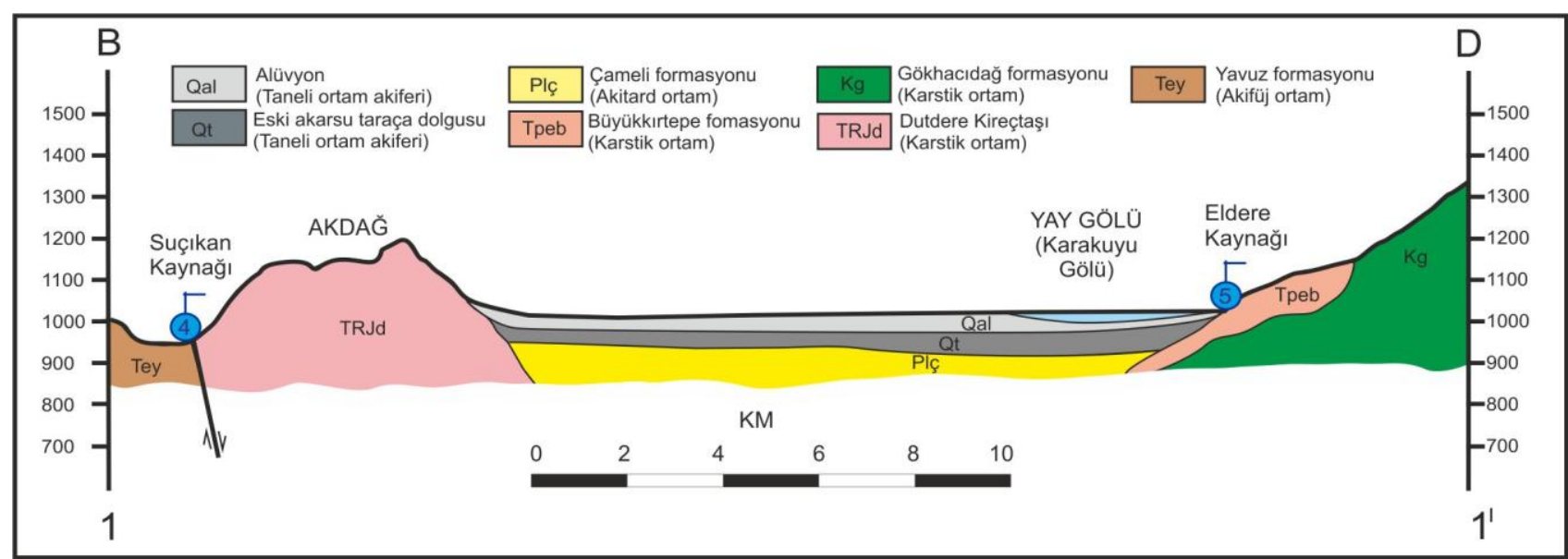

Şekil 3. Suçıkan ve Eldere kaynağına ait kesit 
kaynağı şeklinde de anılmaktadır. Kaynağın debisi yaklaşık $2 \mathrm{~m}^{3} / \mathrm{s}^{\prime} \operatorname{dir}[12]$. Ayrıca, kaynak dipten ve çevredeki dağ yamaçlarından gelen mevsimlik akarsularla da beslenir. Bu akarsuların en önemlisi olan Kumalar çayı, Sandıklı Ovası'nın güneydoğu kesimlerinden yüzeye çıkar ve Karakuyu beldesi güneyinde bulunan Yay Gölü'ne dökülür. Yay Gölü, 1099 hektarlık bir alana sahiptir. DSİ XVIII. Bölge Müdürlüğü, Kocapınar kaynak sularını Karakuyu mevkiinde depolayarak büyük bir sulak alan meydana getirip, 1990 yılında su tutmaya başlamış ve göl suyunu çevre arazileri sulu tarıma açmak, taşkından korumak ve enerji üretmek amacıyla kullanmaya başlamıştır. Yay Gölü, Karakuyu Gölü, Karakuyu Sazlıkları, Çapalı Gölü ve İncesu Gölü olarak da bilinmektedir. Yay Gölü, 1994 tarihinde ise Orman Bakanlığınca "Yaban Hayatı Koruma Sahası" statüsüne alınmış ve aynı yıl Kültür ve Turizm Bakanlığınca "I. Derece Tabiat Sit Alanı" olarak ilan edilmiştir [13, 14]. Karakuyu sulak alanı seddeler içine hapsedilmeden önce sularını Akdağ eteklerinde yer alan düdenler vasıtası ile yeraltına iletiyordu. Yeraltındaki sular batıdaki Suçıkan ve Düden kaynakları vasıtası ile yüzeye çıkmaktadır. Sonradan yapılan müdahale ile sulak alan suları kanal içine alınarak yapay gideğen oluşturulmuştur. Regülatörden ve sulak alan dıșındaki tahliye kanallarından alınan sular $3 \mathrm{~km}$ uzunluğundaki beton bir kanalda bir araya getirilerek Suçıkan kaynağı doğusunda Kazanlık sırtında açılan tünel vasıtasıyla Dinar'a gönderilmekte ve Kanlıkaya Tepe batısında Dinar hidroelektrik santraline (Dinar II-HES) verilmektedir [12].

Suçıkan kaynağı: Kaynak, Dutdere kireçtaşı ve Yavuz formasyonu dokanağından boşalan fay kontrolü bir kaynaktır (Şekil 3). Büyük Menderes Nehri'nin kaynağı ve çıkış noktası olarak kabul edilen kaynak civarında bulunan karbonat kayaçlar oldukça geniş yayılıma sahiptir. Karbonatlar, Barla Dağı'nın üst kesimlerindeki Tekke Tepe (1788 m) çevresinde, Suçıkan kaynağının çıktığı kesimde yüzeylenmektedir. Suçıkan kaynağına güneyden gelen Düden kaynağının suları da karışmaktadır. Yüksek debilere sahip bu kaynaklar Dinar ovasına uzanarak Büyük Menderes Nehri'ni doğururlar. Özellikle Suçıkan kaynağı yüksek verimi ile şelale şeklinde akmaktadır ve civarında çeşitli tesisler (park, mesirelik, otel, yarı olimpik yüzme havuzu, alabalık tesisi vb.) kurulmuştur.

Düden kaynağı: Kaynak, Dinar'ın doğusunda yer alan Bülüçalan köyünün batısında yer almaktadır. Kaynak düden yapısı içinde göl alanına dönüşmüş bir sulak alan şeklindedir.

Ilıca ve İncirli kaynakları: Kaynaklar, Dinar yerleşim merkezi içerinde yer almaktadır. Kaynakların debileri yüksek olduğundan, üzerlerine alabalık tesisleri yapılmıştır. Ilıca kaynağı üzerindeki tesis işletmede değilken, İncirli kaynağı üzerindeki tesis halen aktif olarak işletilmektedir.

Pınarlı kaynağı: Kaynak, Pınarlı köyünde yer almaktadır. Köyün güneyinde yer alan dağın yamaçlarından çıkmaktadır. Çameli formasyonuna ait kireçtaşlarından boşalan kaynağın debisi düşüktür.

İnceleme alanında bu kaynakların yanı sıra kireçtaşlarında düden ve karstik kaynak şeklinde çok sayıda kaynak çıkışları da bulunmaktadır.

Ayrıca bölgede kaynakların yüzeysel akışı verimli bir şekilde beslemesi sonucu Katır çay üzerinde sulama amaçlı göletler (Yeşilçat ve Pınarlı) inşa edilmiştir.

\subsection{Hidrojeokimya}

Havzada bulunan su kaynaklarının hidrojeokimyasal özellikleri, kalitesi ve kullanım koşullarının tespiti için toplam 6 ayrı lokasyondan su örnekleri alınmıştır. Örnekler Ilıca (1), Düden (2), İncirli (3), Suçıkan (4), Eldere (5) ve Pınarlı (6) kaynaklarından alınmıştır. 5 nolu Eldere kaynağı örneği Dinar havzasının dışında kalmaktadır ancak bu kaynaktan Dinar yerleşim merkezinin içme suyu elde edildiği için kaynak çalışma alanı içinde değerlendirilmiştir.

\subsubsection{Fiziksel ve kimyasal özellikler}

Alınan örneklerde, sicaklık (T; $\left.{ }^{\circ} \mathrm{C}\right)$, elektriksel iletkenlik (EC; $\mu \mathrm{S} / \mathrm{cm})$, toplam çözünmüş katı madde (TDS; mg/L), çözünmüş oksijen (DO; mg/L), redoks potansiyeli (Eh; $\mathrm{mV}$ ) ve hidrojen iyonu konsantrasyonu (pH) gibi fiziksel özellikler yerinde ölçülmüştür. Çalışma alanındaki kaynak sularının pH değerleri 7.54-8.76 arasındadır ve bu sular "Bazik karakterli" sulardır. Ayrıca kaynak suların sıcaklıkları 15.50-19.90 ${ }^{\circ} \mathrm{C}$, elektriksel iletkenlikleri 300-700 $\mu \mathrm{S} / \mathrm{cm}$, toplam çözünmüş katı madde miktarı 110$402 \mathrm{mg} / \mathrm{L}$, çözünmüş oksijen miktarı 0.06-0.10 mg/L ve redoks potansiyeli 242.5-340.0 mV arasında değişmektedir. Kaynak sularının sertliği ise 15.76-

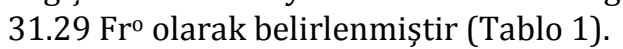

Kimyasal analiz sonuçlarına göre inceleme alanındaki kaynak sularında genel olarak majör katyon ve anyon dizilimi $\mathrm{Ca}^{+2}>\mathrm{Mg}^{+2}>\mathrm{Na}^{+}>\mathrm{K}^{+}$ve $\mathrm{HCO}_{3}>\mathrm{SO}_{4}{ }^{-2}>\mathrm{Cl}^{-}>\mathrm{CO}_{3}{ }^{-2}$ şeklindedir. Özellikle sularda $\mathrm{Ca}^{+2}, \mathrm{Mg}^{+2}$ ve $\mathrm{HCO}_{3}{ }^{-}$ iyonları baskındır. Çalışma alanında karstik birimler (Dutdere kireçtaşı, Kireçtaşı üyesi, Gökhacıdağ formasyonu (dolomit mercekli kireçtaşı), ve Büyükkırtepe formasyonu (resifal kireçtaşı)) hakim konumdadır. Suların yeraltında kalsiyum ve karbonatça zengin minerallerle temas etmesi halinde karbonatlı minerallerde çözünme olur. Bu nedenle inceleme alanındaki kaynak suları su-kayaç ilişkisine bağlı olarak kireçtaşları ile etkileşim halinde olacağından $\mathrm{Ca}^{+2}, \mathrm{Mg}^{+2}$ ve $\mathrm{HCO}_{3}{ }^{-}$iyonları etkisini göstermektedir. 
Tablo 1. İnceleme alanındaki su kaynaklarının analiz sonuçları

\begin{tabular}{|c|c|c|c|c|c|c|c|}
\hline \multirow{2}{*}{\multicolumn{2}{|c|}{$\begin{array}{l}\text { Kaynak Adı } \\
\text { Fiziksel Özellikler }\end{array}$}} & \multirow[t]{2}{*}{ Ilica } & \multirow[t]{2}{*}{ Düden } & \multirow[t]{2}{*}{ İncirli } & \multirow[t]{2}{*}{ Suçıkan } & \multirow[t]{2}{*}{ Eldere } & \multirow[t]{2}{*}{ Pınarlı } \\
\hline & & & & & & & \\
\hline $\mathbf{T}$ & ${ }^{\circ} \mathrm{C}$ & 19.20 & 15.50 & 16.00 & 17.80 & 16.90 & 19.90 \\
\hline EC & $\mu \mathrm{S} / \mathrm{cm}$ & 300 & 400 & 500 & 700 & 699 & 698 \\
\hline pH & & 8.76 & 8.72 & 7.93 & 7.71 & 7.88 & 7.54 \\
\hline Eh & $\mathbf{m V}$ & 242.5 & 286.3 & 298.7 & 297.7 & 284.5 & 340 \\
\hline TDS & $\mathrm{mg} / \mathbf{l}$ & 110 & 152 & 210 & 160 & 400 & 402 \\
\hline DO & mg/l & 0.10 & 0.07 & 0.07 & 0.06 & 0.07 & 0.07 \\
\hline Sertlik & Fro & 23.05 & 31.29 & 26.12 & 20.41 & 15.76 & 23.80 \\
\hline \multicolumn{8}{|c|}{ Majör Elementler } \\
\hline $\mathrm{Ca}^{+2}$ & $\mathrm{mg} / \mathrm{l}$ & 49.06 & 90.30 & 68.04 & 51.35 & 45.71 & 78.13 \\
\hline $\mathbf{M g}^{+2}$ & $\mathrm{mg} / \mathrm{l}$ & 26.29 & 21.30 & 22.24 & 18.49 & 10.58 & 10.47 \\
\hline $\mathrm{Na}^{+}$ & $\mathrm{mg} / \mathrm{l}$ & 11.98 & 8.17 & 9.23 & 7.48 & 2.93 & 4.52 \\
\hline $\mathbf{K}^{+}$ & mg/l & 2.95 & 1.59 & 1.38 & 2.14 & 1.04 & 0.77 \\
\hline $\mathrm{Cl}^{-}$ & mg/l & 4.86 & 4.86 & 4.91 & 4.01 & 1.89 & 3.75 \\
\hline $\mathrm{SO}_{4}^{-2}$ & $\mathrm{mg} / \mathbf{l}$ & 11.39 & 15.56 & 16.86 & 6.15 & 2.41 & 10.63 \\
\hline $\mathrm{HCO}_{3}^{-}$ & $\mathrm{mg} / \mathrm{l}$ & 298.9 & 359.9 & 298.9 & 250.1 & 195.2 & 262.3 \\
\hline $\mathrm{CO}_{3}-2$ & $\mathrm{mg} / \mathrm{l}$ & 0 & 0 & 0 & 0 & 0 & 0 \\
\hline \multicolumn{8}{|c|}{ Azot Türevleri } \\
\hline $\mathrm{NO}_{2}^{-}$ & $\mathrm{mg} / \mathrm{l}$ & 0 & 0 & 0 & 0 & 0 & 0 \\
\hline $\mathrm{NO}_{3}^{-}$ & mg/l & 2.74 & 8.45 & 10.40 & 3.32 & 5.55 & 10.76 \\
\hline $\mathrm{NH}_{4}{ }^{+}$ & $\mathrm{mg} / \mathrm{l}$ & 0.11 & 0.15 & 0.13 & 0.24 & 0.03 & 0.47 \\
\hline \multicolumn{8}{|c|}{ İz Elementler } \\
\hline Al & $\mu \mathrm{g} / \mathrm{l}$ & 4 & 11 & 6 & 18 & 4 & 3 \\
\hline As & $\mu \mathrm{g} / \mathrm{l}$ & 11 & 9.80 & 12.90 & 17.40 & 13.40 & 13.60 \\
\hline B & $\mu \mathrm{g} / \mathrm{l}$ & 53 & 36 & 41 & 30 & 8 & 6 \\
\hline Ba & $\mu \mathrm{g} / \mathbf{l}$ & 114.70 & 51.53 & 46.58 & 69.26 & 123.45 & 38.53 \\
\hline $\mathrm{Br}$ & $\mu \mathrm{g} / \mathbf{l}$ & 30 & 28 & 30 & 25 & 12 & 20 \\
\hline Cd & $\mu \mathrm{g} / \mathrm{l}$ & $<0.05$ & $<0.05$ & $<0.05$ & $<0.05$ & $<0.05$ & $<0.05$ \\
\hline $\mathrm{Cr}$ & $\mu \mathrm{g} / \mathrm{l}$ & 2.30 & 2.20 & 5.90 & 2.80 & 2.70 & 2.90 \\
\hline $\mathrm{Cu}$ & $\mu \mathrm{g} / \mathrm{l}$ & 1.30 & 1.30 & 1.70 & 0.90 & 1.70 & 0.40 \\
\hline $\mathbf{F e}$ & $\mu \mathrm{g} / \mathrm{l}$ & $<10$ & $<10$ & $<10$ & $<10$ & $<10$ & $<10$ \\
\hline Hg & $\mu \mathrm{g} / \mathrm{l}$ & $<0.10$ & $<0.10$ & $<0.10$ & $<0.10$ & $<0.10$ & $<0.10$ \\
\hline
\end{tabular}

Tablo 2. İnceleme alanındaki kaynakların Chadha diyagramı ile sınıflaması [2]

\begin{tabular}{clc}
\hline $\begin{array}{c}\text { Alt } \\
\text { Alan }\end{array}$ & \multicolumn{1}{c}{ Sınıflandırma } & $\begin{array}{c}\text { Su kaynağı } \\
\text { örneği no }\end{array}$ \\
\hline 1 & Alkali toprak elementleri, alkali elementlerden fazladır & \\
2 & Alkali elementler, alkali toprak elementlerinden fazladır & \\
3 & Zayıf asit kökleri, güçlü asit köklerinden fazladır \\
4 & $\begin{array}{l}\text { Güçlü asit kökleri, zayıf asit köklerinden fazladır } \\
5\end{array}$ & $\begin{array}{l}\text { Alkali toprak elementleri ve zayıf asit kökleri, alkali elementler ve güçlü asit köklerinin her } \\
\text { ikisinden de fazladır }\end{array}$ \\
6 & $\begin{array}{l}\text { Alkali toprak elementleri, alkali elementlerden fazladır ve güçlü asit kökleri, zayıf asit köklerinden } \\
\text { fazladır }\end{array}$ \\
7 & $\begin{array}{l}\text { Alkali elementler, alkali toprak elementlerinden fazladır ve güçlü asit kökleri, zayıf asit köklerinden } \\
\text { fazladır }\end{array}$ \\
8 & $\begin{array}{l}\text { Alkali elementler, alkali toprak elementlerinden fazladır ve zayıf asit kökleri, güçlü asit köklerinden } \\
\text { fazladır }\end{array}$ \\
\hline
\end{tabular}

Piper [1] diyagramına göre Ilıca, Düden, İncirli, Suçıkan ve Eldere kaynaklarına ait sular $\mathrm{CaMgHCO}_{3} \mathrm{Ml}_{\mathbf{l}}$ su tipinde, Pınarlı kaynağındaki sular ise $\mathrm{CaHCO}_{3}{ }^{\prime} \mathrm{l}_{1}$ su tipindedir (Şekil 4).

Chadha [2] doğal suların hidrojeokimyasal işlevlerini 8 ayrı kategoride sınıflandıran bir diyagramdır (Tablo 2). Çalışma alanındaki kaynak sularının tamamı 5 nolu alt alana düșmektedir. Bu alandaki sular şu özelliktedir; "alkali toprak elementleri (Ca, $\mathrm{Mg})$ ve zayıf asit kökleri $\left(\mathrm{CO}_{3}, \mathrm{HCO}_{3}\right)$, alkali elementler $(\mathrm{Na}, \mathrm{K})$ ve güçlü asit köklerinin $\left(\mathrm{SO}_{4}, \mathrm{Cl}\right)$ her ikisinden ayrı ayrı fazladır". Bu sular geçici sertliğe sahip olan sulardır. Diyagram üzerindeki noktaların pozisyonu, $\mathrm{CaMgHCO}_{3}$ tip, $\mathrm{CaMg}$ yüksek $\mathrm{HCO}_{3}$ tip veya $\mathrm{HCO}_{3}$ yüksek $\mathrm{CaMg}$ tip suları yansıtmaktadır. Havzadaki kaynak suları Chadha diyagramına göre $\mathrm{CaMgHCO}_{3}$ tip sulardır (Şekil 5).

Akiferin litolojik özellikleri ile suların bileşimi arasındaki ilişkiyi belirlemek için Gibbs diyagramları yaygın olarak kullanılmaktadır [3]. Diyagramlarda Eşitlik 1'de verilen oranlara göre suların kimyası üzerinde su-kayaç etkileşimi, buharlaşma ya da yağışın etkin olup olmadığı belirlenmektedir. Şekil 6' ya göre çalışma alanındaki su kaynaklarının tamamı "su-kayaç etkileşimi"nin etkin olduğu alanda yer almaktadır. 


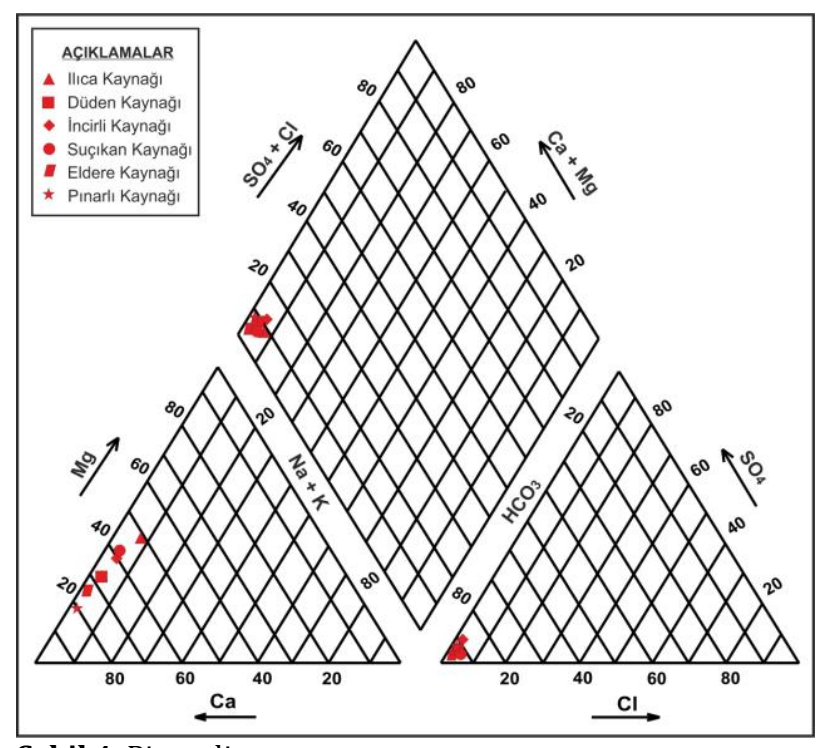

Şekil 4. Piper diyagramı

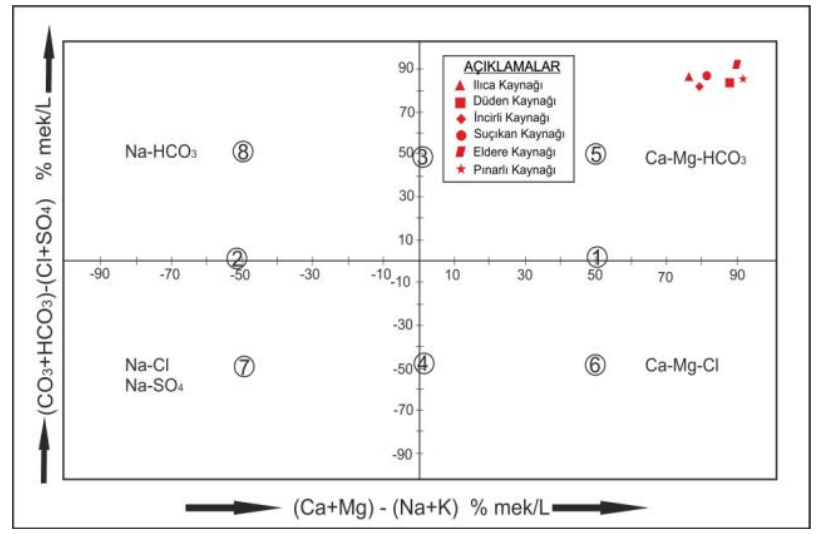

Şekil 5. Chadha diyagramı

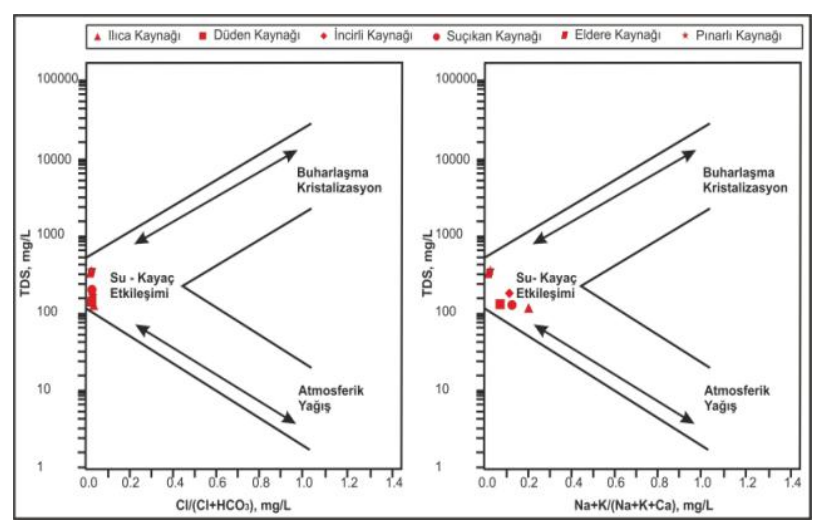

Şekil 6. Gibbs diyagramı

Gibbs Oranı I (anyonlar için) $=\mathrm{Cl}-/\left(\mathrm{Cl}^{-}+\mathrm{HCO}_{3}{ }^{-}\right)$

Gibbs Oranı II (katyonlar için) $=\mathrm{Na}^{+}+\mathrm{K}^{+} /\left(\mathrm{Na}^{+}+\mathrm{K}^{+}+\mathrm{Ca}^{+2}\right)$

İçilebilirlik: Çalışma alanındaki su kaynaklarının içilebilir olma özelliğini belirlemek için Schoeller içilebilirlik diyagramı kullanılmıştır. Diyagrama göre su kaynaklarının tamamı "içilebilir özellikte sular" sınıfında yer almaktadır. Ilıca, Düden ve İncirli kaynak suları, "çok iyi kaliteli sular" sınıfında iken Suçıkan, Eldere ve Pınarlı kaynaklarına ait sular

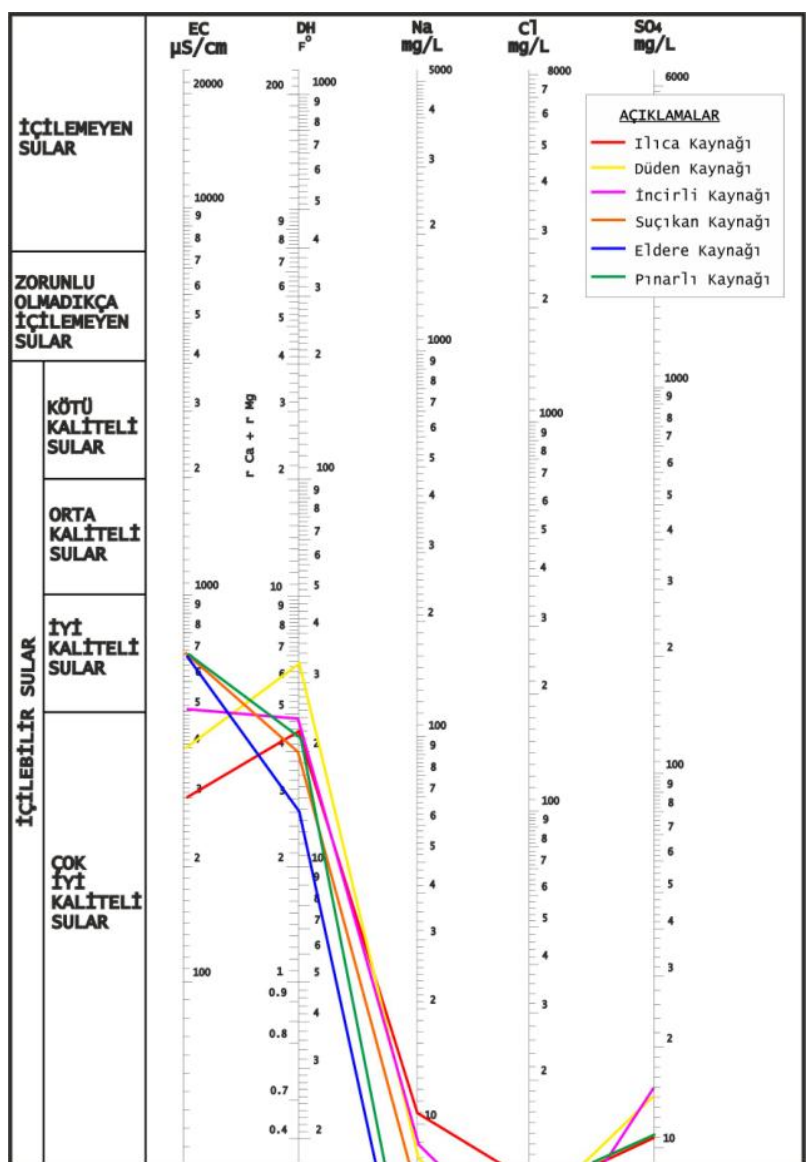

Şekil 7. Schoeller içilebilirlik diyagramı

ise "iyi kaliteli sular" sınıfında yer almaktadır (Şekil 7). Ayrıca, çalışma alanındaki kaynak suları fiziksel özellikleri ve majör elementleri açısından Dünya Sağlık Örgütü (WHO) [15] ve TSE-266 Türk İçme Suyu Standartları'na (TSE-266) [16] göre de uygundur.

Sulamada kullanılabilirlik: Çalışma alanındaki kaynak sularının tarımsal alanlarda sulama amaçlı olarak kullanılabilirliğini belirlemek için ABD Tuzluluk Laboratuvarı [4] ve Wilcox [5] diyagramları kullanılmaktadır. Kaynak suları ABD Tuzluluk Laboratuvarı diyagramına göre "C2S1" sinıfında yer almaktadır (Şekil 8). Bu sinıftaki sular "orta tuzlu az sodyumlu sular" şeklinde nitelendirilmektedir. Wilcox diyagramında ise tüm kaynak suları "çok iyi kullanılabilir" sular sınıfındadır (Şekil 9).

\subsubsection{Su kirliliği}

Çalışma alanında halkın geçim kaynağı tarımdır. Tarımda kullanılan zirai ilaç, gübre vb. maddelerin su kaynaklarına etkisini belirleyebilmek için azot türevleri $\left(\mathrm{NO}_{3}^{-}, \mathrm{NO}_{2}^{-}, \mathrm{NH}_{4}^{+}\right)$analiz sonuçları değerlendirilmiştir. Ayrıca suların jeojenik ve antropojenik unsurlara bağlı olarak kirlilik durumu ile ilgili bilgi veren iz element ( $\mathrm{Al}, \mathrm{As}, \mathrm{B}, \mathrm{Ba}, \mathrm{Br}, \mathrm{Cd}, \mathrm{Cr}$, $\mathrm{Cu} \mathrm{Fe}, \mathrm{Hg}, \mathrm{Li}, \mathrm{Mn}, \mathrm{Ni}, \mathrm{Pb}, \mathrm{U}, \mathrm{Zn}$ ) analizleri de değerlendirilmiştir (Tablo 1). 


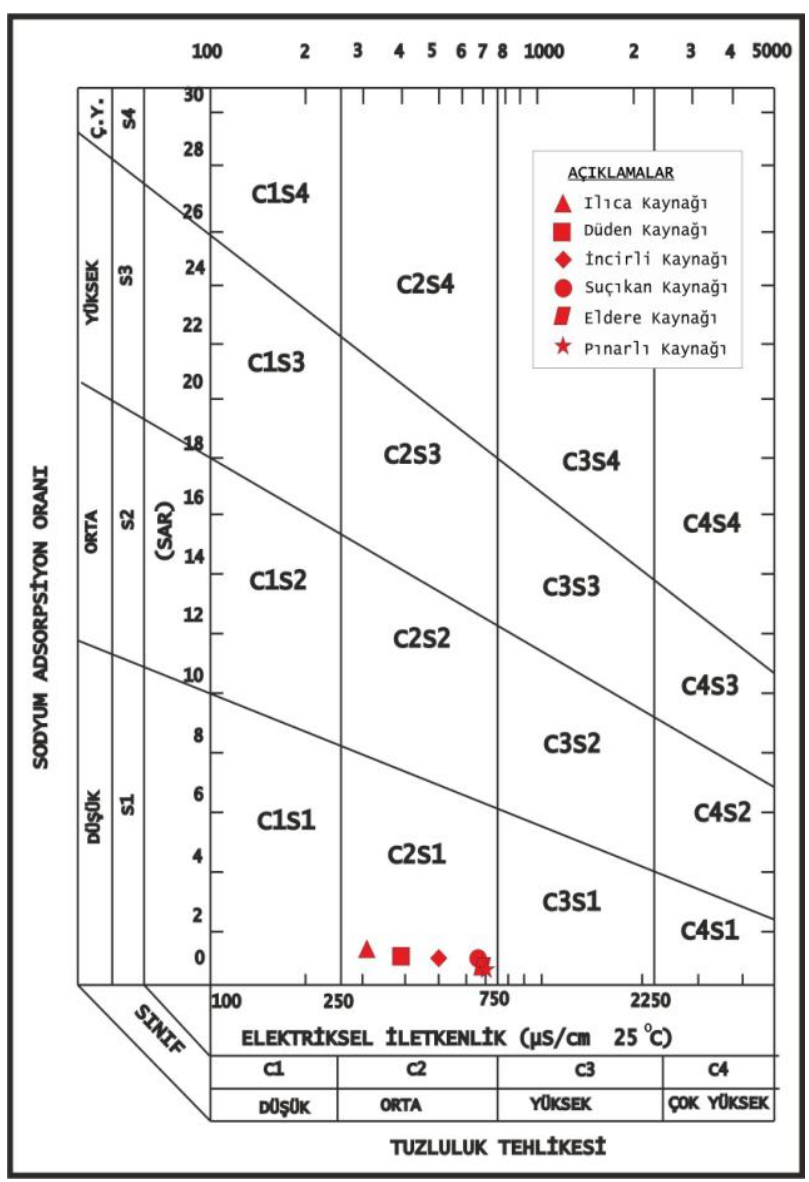

Şekil 8. ABD tuzluluk laboratuvarı diyagramı

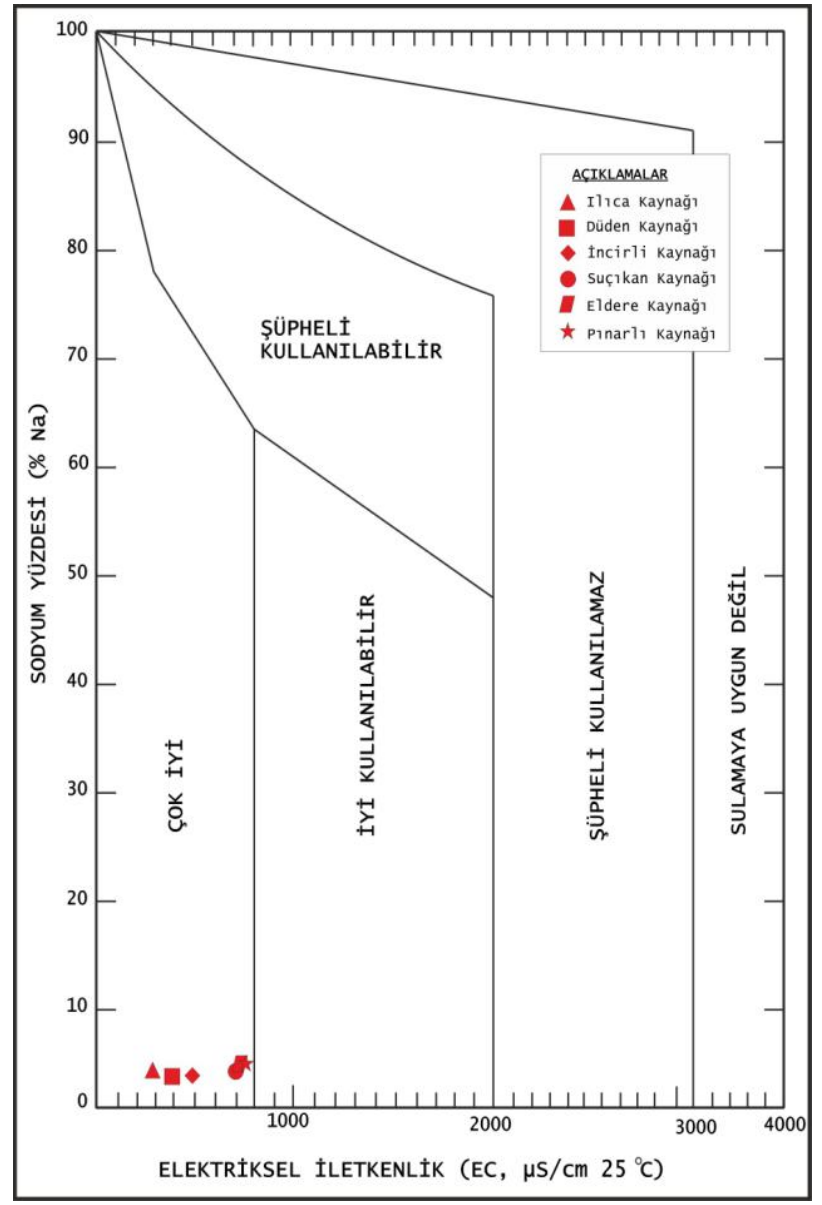

Şekil 9. Wilcox diyagramı
Azot türevleri: Çalışma alanındaki nitrat, nitrit ve amonyum konsantrasyon değişimleri 2.74-10.76, 0-0, ve $0.03-0.47 \mathrm{mg} / \mathrm{L}$ olarak değișmektedir (Tablo 1). Çalışma alanındaki kaynak sularının nitrat, nitrit ve amonyum konsantrasyonları WHO [15] ve TSE-266 [16] içme suyu standartları sınır değerlerini aşmamaktadır.

İz elementler: Genel olarak kaynak sularının tamamında arsenik hariç, iz element konsantrasyon değerleri WHO [15] ve TSE-266 [16] içme suyu standartları sınır değerlerini aşmamaktadır.

İnceleme alanında arsenik (As) konsantrasyonu 9.80$17.40 \mu \mathrm{g} / \mathrm{L}$ arasında değişmektedir (Tablo 1). Kaynak sularındaki arsenik konsantrasyon değerleri; Ilıca $(11.00 \mu \mathrm{g} / \mathrm{L})$, Düden (9.80 $\mu \mathrm{g} / \mathrm{L})$, İncirli $(12.90 \mu \mathrm{g} / \mathrm{L})$, Suçıkan $(17.40 \mu \mathrm{g} / \mathrm{L})$, Eldere $(13.40 \mu \mathrm{g} / \mathrm{L})$ ve Pınarlı (13.60 $\mu \mathrm{g} / \mathrm{L})$ 'dir. Arseniğin içme suyu olarak kullanımında WHO [15] ve TSE-266 [16] standartları tarafından belirlenen sınır değeri $10 \mu \mathrm{g} / \mathrm{L}$ 'dir. Çalışma alanındaki kaynak örneklerinde As içeriği Düden kaynağı hariç sınır değeri (>10 $\mu \mathrm{g} / \mathrm{L})$ aşmaktadır.

Batı Anadolu'da arsenik, bazı tortul kayaçlarda bulunmasına ek olarak, volkanik olușumların alterasyon zonlarında da tipik olarak gözlenmektedir [17]. Kaynak sularının çalışma alanında yayılım gösteren Kızılcadağ melanjı ve olistostromunu içerisinde yer alan spilitik bazalt, tüf ve tüfit vb. kayaçlarla etkileşimi sonucu arsenik konsantrasyonun da artış görülebilir. İçme sularındaki yüksek arsenik konsantrasyonunun insanlarda kanseri artırdığı bilinmektedir [18, 19]. Kaynak suları bölgede içme suyu olarak kullanıldığı için As artışı tehdit unsuru oluşturabilmektedir. Uzun süreli As içerikli su tüketimi insan sağlığı açısından tehlikelidir. Bu nedenle içme suyu olarak kullanılan kaynak sularındaki arsenik konsantrasyon artışının kontrol altına alınması gerekmektedir.

\section{Tartışma ve Sonuç}

Çalışma alanında bulunan su kaynakları içme ve sulama amaçlı kullanıldıkları için bu suların kimyasal olarak değerlendirilmesi su kalitesi açısından büyük önem taşımaktadır. Çalışma alanının en önemli akiferleri Dinar ovasını oluşturan taneli ortam akiferi ve su kaynaklarının beslenim kaynağı olan karstik ortam akiferidir. İnceleme alanındaki kaynak suları $\mathrm{Ca}^{+2}>\mathrm{Mg}^{+2}>\mathrm{Na}^{+}>\mathrm{K}^{+}$ve $\mathrm{HCO}_{3}>\mathrm{SO}_{4}{ }^{-2}>\mathrm{Cl}^{-}>\mathrm{CO}_{3}{ }^{-2}$ şeklinde iyon dizilimi göstermiştir. Kaynak sularında genel olarak $\mathrm{Ca}^{+2}$ ve $\mathrm{HCO}_{3}$ - iyonları baskın konumdadır ve bu sular $\mathrm{CaMgHCO}_{3}{ }^{\prime}$ lı su tipine, Pınarlı su kaynağı ise $\mathrm{CaHCO}_{3}{ }^{\prime} \mathrm{l}$ su tipine sahiptir. Sularda bu su tiplerinin etkin olması, suların çalışma alanında geniş yayılıma sahip olan karstik birimlerin içerisindeki kalsiyum ve karbonatça zengin minerallerle etkileşim halinde olmasindan kaynaklanabilmektedir. $\mathrm{Bu}$ durum kaynak sularının Gibbs diyagramına göre de su-kayaç 
etkileşimli bölgede olması ile de desteklenebilmektedir. Kaynak suları Schoeller içilebilirlik diyagramına göre "çok iyi-iyi kaliteli sular" sınıfındadır. Bölgedeki suların sulama suyu olarak kullanımı incelendiğinde ABD Tuzluluk Laboratuvarı diyagramı ile "C2S1 (orta tuzlu az sodyumlu sular)" sinıfında Wilcox diyagramına göre de "çok iyi kullanılabilir sular" sınıfında olduğu değerlendirilmiştir. Ayrıca, kaynak suları kirlilik parametreleri açısından değerlendirildiğinde azot türevleri açısından herhangi bir kirliliğe rastlanılmamıștır. İz element analiz sonuçlarına göre ise örneklerde As konsantrasyon artışı gözlenmiştir. Kaynak sularındaki arsenik konsantrasyon artışının jeojenik olarak Kızılcadağ melanjı ve olistostromunu içerisinde yer alan spilitik bazalt, tüf ve tüfit vb. kayaçlarla etkileşim sonucu olduğu düşünülmektedir. İnsan sağlığı açısından As içeren suların uzun süreli kullanımının hayati açıdan risk oluşturması nedeniyle sularda gerekli önlemlerin alınması gerekmektedir.

\section{Teşekkür}

$\mathrm{Bu}$ çalışmanın yapılmasını destekleyen TÜBİTAK 2209/A Üniversite Öğrencileri Yurtiçi Araștırma Projeleri Destek Programı'na teşekkürlerimizi sunarız.

\section{Kaynakça}

[1] Piper, A.M. 1944. A graphical procedure in the geochemical interpretation of water analysis. Am Geophys Union Trans, 25, 914-928.

[2] Chadha, D.K. 1999. A Proposed New Diagram For Geochemical Classification of Natural Waters and Interpretation of Chemical Data. Hydrogeology Journal, 7, 431-439.

[3] Gibbs, R.J. 1970. Mechanism controlling world water chemistry. The Sciences, 170, 795-840.

[4] Richards, L.A. 1954. Diagnosis and improvement of saline alkali soils. Agriculture handbook, Vol.78, No.2, 154p LWW.

[5] Wilcox, L.V. 1955. Classification and use of irrigation water. USDA Circular, Washington DC, 969p.

[6] Şenel, M. 1997a. 1:100.000 ölçekli Türkiye Jeoloji Haritaları Denizli-K9 paftası. Maden Tetkik ve Arama Müdürlügü Jeoloji Etüt Dairesi yayını, 17, Ankara.

[7] Şenel, M. 1997b. 1:100.000 ölçekli Türkiye Jeoloji Haritaları Isparta J-11 paftası. Maden
Tetkik ve Arama Müdürlügü Jeoloji Etüt Dairesi yayını, 14, Ankara.

[8] Öztürk, E.M., Öztürk, Z. 1989. Balçıkhisar, Karadilli Afyon Dereköy Isparta Dolayının Jeolojisi. MTA Rapor, 8946 (yayınlanmamış), Ankara.

[9] Şenel, M. 1997c. 1:100.000 ölçekli Türkiye Jeoloji Haritaları Isparta J-10 paftası. Maden Tetkik ve Arama Müdürlüğü Jeoloji Etüt Dairesi yayını, 13, Ankara.

[10] Balcl, V. 2011. 1:100 000 ölçekli Türkiye Jeoloji Haritaları Afyon L-24 paftası. Maden Tetkik ve Arama Genel Müdürlüğü Jeoloji Etüt Dairesi yayını, 162, Ankara.

[11] FugroSíAL, 2014. Yukarı Büyük Menderes havzası (Küfi) yeraltısuyu planlama (hidrojeolojik etüt) raporu, 396s.

[12] Polat, S., Güney, Y., Deniz, M. 2011. Karakuyu Gölü sulak alanı ve başlıca problemleri. Uluslararası Katılımlı Coğrafya Kongresi, 07-10 Eylül 2011, İstanbul, (70. Yıl anısına), 450-467.

[13] AİÇDR, 2011. Afyonkarahisar İli Çevre Durum Raporu. Afyonkarahisar Valiliği Çevre ve Şehircilik İl Müdürlüğü, Afyonkarahisar, 508s.

[14] Bulut, İ., Karapınar, B.Ç., Özoğul, B. 2016. Karakuyu Gölü (Afyonkarahisar-Dinar) ve Yüzen Adaları. TÜCAUM Uluslararası Coğrafya Sempozyumu, International Geography Symposium, 13-14 Ekim 2016, Ankara, 366-378.

[15] WHO, 2011. Guidelines for drinking-water quality. 4th edition, World Health Organization.

[16] TSE-266, 2005. İnsani tüketim amaçlı sular. Türk İçme Suyu Standartları TSE 266 sayılı standart-Türk Standartları Enstitüsü -Ankara.

[17] Baba, A., Sözbilir, H. 2012. Source of arsenic based on geological and hydrogeochemical properties of geothermal systems in Western Turkey. Chemical Geology, 334, 364-377.

[18] Chatterjee, A., Mukherjee, A. 1999. Hydrogeological investigation of ground water arsenic contamination in South Calcutta. Science of the Total Environment, 225(3), 249-262.

[19] Baba, A., Gunduz, 0. 2017. Effect of geogenic factors on water quality and its relation to human health around Mount Ida, Turkey. Water, 9,66, DOI 10.3390/w9010066. 